\title{
How far has international HRM travelled? A systematic review of literature on multinational corporations (2000-2014)
}

Fang Lee Cooke, Alex Veen, and Geoffrey Wood

\section{Abstract}

This article reviews the present state of research on multinational corporations (MNCs) in the international human resource management (IHRM) literature. Drawing on 342 articles from 39 English journals in the business and management field published over the period of 20002014, we identify three key strands within this section of the IHRM scholarly field (MNC country of origin/domicile effects; expatriates management; and, intra-organizational knowledge and strategy flows). Building up on our detailed assessment of trends in the literature based on a systematic review, we propose areas where the field could be developed and extended through drawing on insights from, and building synthesis with, cognate fields. We conclude that major developments on the ground - the increasing numbers of unskilled expatriate workers, the rise of MNCs from emerging markets, and the growth of transnational alternative investors - have the potential to transform the field of enquiry, yet are only starting to appear in the IHRM literature. In developing new major areas of enquiry - and in extending existing ones - insights may be drawn from the literature on comparative institutional analysis to take fuller account of trans-national actors.

Key words: alternative investors; cultural perspectives; expatriates; institutional theories; international human resource management; multinational corporation 


\title{
1. Introduction
}

There is now a substantial body of research on human resource management (HRM) in multinational corporations (MNCs) as a result of individual and collective efforts from scholars in the field of international HRM (IHRM) since the mid-1980s. A number of review studies have also been conducted by leading scholars that provide insightful evaluations of the field in terms of thematic foci, analytical approaches and research gaps (e.g., Schuler et al., 2002; Scullion \& Paauwe, 2004; De Cieri et al., 2007; Björkman \& Welch, 2015; Brewster et al., 2016; Cooke et al., 2017). A major critique from earlier scholarly reviews is that research in IHRM, or more specifically, HRM in MNCs, has for too long focused rather narrowly on expatriate management (e.g., De Cieri et al., 2007). Other key concerns in the literature have been the effect of contextual circumstances (culture and institutions), and intra-organizational ties and knowledge flows. An emerging and open-ended challenge is broadening the scope of the traditionally quite closely circumscribed debates, opening the potential for more holistic and integrated accounts. However, the majority of the scholarly reviews of HRM in MNCs studies were based on the rich knowledge of the authors in the field or focused on particular aspects, often certain HRM functions, as the main focus of the review (see Table 1 for a summary). As indicated in Table 1, due to their other priorities, few of these review articles on HRM in MNCs have conducted a systematic literature search on the topic for a more thorough stock taking. As such, our understanding of the state of affairs in the field of HRM in MNCs remains partial. We do not have a clear overview, informed by a comprehensive review, to identify changes in research agenda, and to inform our future research efforts in this important field.

\author{
Insert Table 1 about here
}


In this systematic and comprehensive review, we update and extend earlier reviews by taking fuller account of major new developments and trends, for instance, the increasingly visible role of unskilled expatriate workers, and the rise of transnational alternative investors and emerging market MNCs. We also explore ways in which the literature may be extended to provide a fuller coverage of them. At a theoretical level, we highlight the potential of recent developments in the literature on comparative institutional analysis for deepening the theoretical bases of the literature on IHRM. Our study draws attention to recent developments and trends which challenge the way HRM has traditionally been understood in the MNCs. Welch and Bjorkman (2015) focused on the increasing prominence of IHRM research in international business outlets. We extend their argument by suggesting that it is important to assess how the IHRM scholarship has matured and how the field can be further developed by adopting a broader research agenda and theoretical underpinning. Our intention is two-fold: to provide a relatively comprehensive appraise of the field; and to help raise future research capacity by providing directions to researchers.

This review paper contains four main sections in addition to this introduction and a conclusion. The first section outlines methods of data collection and analysis. This is followed by a discussion of the findings of 342 studies included in this review. ${ }^{1}$ We map out what subject matters have been researched and published, which countries have been most studied, what methods and theoretical perspectives have been used, and what implications these findings may have for future studies. We highlight gaps in methods, locations and themes as well as good practices which we believe would be helpful for future research and management practice. The third section summarizes key theoretical debates in the field of HRM in MNCs and their limitations. The final main section points out a number of research

\footnotetext{
${ }^{1}$ A full reference list of the 342 articles used for the review study can be provided by the authors on request.
} 
avenues to reflect trends of and new developments in foreign direct investment (FDI) and its implications for HRM in MNCs.

\section{Methods of data collection and analysis}

\subsection{Data collection}

Data used for this paper consists of articles published in business and management journals (broadly defined to include work and organization, and industrial/employment relations) in English during the period of 2000 and 2014. We chose 2000 as the starting point because we wanted to capture what has taken place in the field of HRM in MNCs since the turn of the century. It is also since the late 1990s when IHRM has developed into a more robust stream of research in the HRM field. Given the large number of studies that have emerged, we felt that 15 years was a convenient cut of point. Our aim was to discern trends with a large sample instead of a population study, although we have tried our best to identify as many articles as possible for the catchment period.

Ebsco, Emerald, ProQuest and Library databases were searched through the university library electronic journal databases, using combined key words: 'multinational' and 'human resource management'; 'multinational' and 'training'; 'multinational' and 'reward'; 'multinational' and 'performance management'; 'multinational' and 'gender'; 'multinational' and 'talent management'; 'international HRM', and so forth. The combination of these two search strategies meant that a comprehensive search was undertaken, which ensured that most of the relevant publications were identified. The search period was set for January 2000December 2014. This enabled an assessment of the progression of the scholarship over time. Two research assistants were employed to do the search. All articles deemed relevant for the purpose of this review paper were downloaded and the first author screened through each of these articles to confirm relevance for the study. A total of 342 articles were included for data 
analysis, 293 of which are empirical (86\%) studies and 49 (14\%) review/perspective articles. These articles were published in 39 business and management journals (see Table 2). The chosen time period allowed us to break down the analysis into three five-year time periods: 2000-2004 (86 articles), 2005-2009 (112 articles), and 2010-2014 (144 articles), indicating that the number of studies have grown substantially since 2000 .

It is important to acknowledge that our search may not have exhausted all the articles published on the topic in the period of our study due to unavailability in the database, search terms used not reflected in the title or key words of articles, or human error (oversight) during the search. However, we are confident that we have located the majority of the articles on the topic in academic journals in our search period. Therefore, this data set enables us to outline what has been studied, where, how, what theories have been used and what gaps might exist.

\section{Insert Table 2 about here}

\subsection{Data coding and analysis}

Each article was entered into an excel file for data coding by one researcher and checked by a co-author to ensure accuracy. Differences in the coding were then discussed with the lead author to reach an agreement. Another co-author then carried random check on the data entry of 40 articles for accuracy. Each article was coded by author(s), year of publication, journal in which the article was published, types of article (empirical vs. review), research methods used, home country and host country/countries of the MNC studied, HRM aspects studied, and theories used to inform the study. The coding categorization was created in order to address the following research questions for the analytical purpose of this paper.

1. What methods have been used (e.g. case study, survey, interviews)? Are these adequate and what are the gaps? 
2. What countries, both home and host, have been the most studied?

3. What has been researched (aspects of HRM)? What has been less researched? Why? What are the consequences/implications for knowledge gaps?

4. What theories have been mobilized to make sense of MNC strategies and patterns of HRM practices? And what implications might these have for the IHRM as a field of research?

5. Are these studies reflecting the trends of FDI and the expansion of MNCs in the global politico-economic landscape?

6. What are some of the areas future studies should focus on (e.g. methods, types of firms, aspects of HRM, industrial sectors)?

For the purpose of this study, empirical articles refer to those that involved first-hand and second-hand empirical data, whereas review papers are those preoccupied with reviewing the state of arts or perspectives of the field. Due to the lack of consistent information, we omitted ownership forms and industries studied in our analysis. Tables were generated from each column to summarize the findings. Some of these tables were then further categorized to discern patterns. We adopted the inductive categorization rather than a priori coding system to enable us to uncover emergent thematic foci in the literature. Themes/HRM practices studied were identified mainly from the title, keywords and subheadings of the articles. They were then grouped into broader categories, such as HRM practices, organizational behavior and so forth. Again, these were coded by one researcher, checked by a co-author and finalized by the lead author. Our approach is similar to Werner (2002) and Pisani (2009) who have conducted systematic reviews of articles on international management published in top 20 management journals in given periods. In the next section, we analyze the main findings. 


\section{Key Findings}

\subsection{Publication outlets}

As shown in Table 2, the majority of the articles were published in The International Journal of Human Resource Management, which accounts for over 30 per cent of the studies reviewed. In addition, publications on HRM in MNCs appear to concentrate in a relatively small number of outlets, with the top ten journals in term of the number of articles making up over 70 percent of our sample. It is noteworthy, however, that the proportion of publications in top journals - measured by Impact Factors, Financial Times Top 50 Journal list, the Chartered Association of Business Schools List of Britain, and the Australian Business Deans' Council journal ranking lists of Australia - remains relatively small and has only increased marginally, particularly in the $2010-2014$ period. Nevertheless, there is a decrease of publications in the lower ranked journals (e.g., Employee Relations and International Journal of Manpower), and a rise in the higher ranked journals (e.g., Human Relations; Human Resource Management; Industrial and Labor Relations Review; and Journal of World Business).

\subsection{Research methods used in the studies}

As shown in Table 3, more than half of the empirical studies in this review relied on qualitative research methods, quantitative research methods were deployed by around 40 percent, while the remaining 10 percent adopted a mixed-method approach. Case studies are a main methodological approach for studies of HRM in MNCs, relying, largely, on interviews with senior, middle, line and HR managers of the headquarters, expatriate and local managers of subsidiaries, expatriates/inpatriates, and local employees. In other words, studies that used interviews as the primary data collection method were predominantly focusing on organizational actors. However, in a small number of studies, other relevant stakeholders such 
as trade union officials, employer association representatives, and other industrial or organizational stakeholders were included (e.g., Bailey, 2009; Dalton \& Druker, 2012). For quantitative studies, surveys were the main method for the empirical data collection and the majority of studies (36 out of 89 ) relied on traditional mail surveys. The vast majority of the studies, both qualitative and quantitative, are cross-sectional that provide a snapshot of the topic examined. Hardly any studies examine the evolution of an MNC's business strategy and HR strategy and reasons for and implications of this evolution on HR practices and employee wellbeing over time. While this large absence is understandable given the difficulty in gaining access for longitudinal studies, this lacuna does highlight an important gap in our knowledge of the growth and decline of MNCs as an important and integral phenomenon of the economic globalization, with consequences for many concerned.

Further analysis of the research methods over the three time periods (2000-2004; 2005-2009; 2010-2014) detects that a discernible shift is taking place. More specifically, there is an increase in the number of quantitative studies in last 5-year period of 2000-2004 (29 articles, 33\% of total of empirical studies of the period); 2005-2009 (34 articles, 30\%), and 2010-2014 (52 articles, 46\%). There may be three main, and related, reasons for this. One is that researchers are increasingly using secondary quantitative data (e.g., the CRANET survey, the INTREPID survey, national government census data, and data from international bodies such as OECD, UNCTAD, and World Bank) for their study as it is increasingly difficult to gain access to MNCs for data collection. Second, this trend is perhaps indicative of the growing preference for positivist studies in good journals, i.e., the favoring of 'quantification' of scholarship in the current politics of publishing (Bryman \& Bell 2015, p. 151). Third, the leaning towards organizational behavior (OB) topics in HRM research more generally in recent years, as observed by a number of scholars (e.g., Godard, 2014; Barry \& Wilkinson, 
2015; Harley, 2015) may account for the modest but steady growing in proportion of quantitative studies.

Some 60 percent of the mail surveys had response rates of 20 per cent or higher. What was found, however, was that there is a considerable level of inconsistency in relation to the reporting of the sample frame, sample size, useful responses, and response rates of survey studies. There is at times a considerable gap between reported response rates and the number of useable responses. The reporting of 'effective' response rates (Simonin \& Özsomer, 2009) gives the reader a much clearer indication of the quality of the data and challenges that researchers faced. Particularly where datasets were derived from multiple locations, it would be insightful to understand the levels of participation across them. Rather than highlighting deficiencies in these areas, we prefer to highlight examples of detailed survey reporting as examples of good practice (c.f., Pudelko \& Harzing 2007; Asmussen et al., 2013). Given the growing popularity of survey methods in MNC HRM studies, it is important that data collection processes are clearly documented to aid assessment of methodological rigor and comparison of different studies.

\section{Insert Table 3 about here}

\subsection{Home and host countries studied}

A total of 36 home countries and 86 host countries have been identified in the studies reviewed, reflecting the pattern of ever increasing globalization of MNC activities (Edwards \& Rees 2016). Table 4 provides an indicative summary of the most studied home and host countries or regions (previous IHRM reviews have not focused on this to reveal less researched sites that deserve more attention). It is indicative because not all empirical studies in the dataset provide a full list of the countries in which their studies were conducted, 
although these are only a minority. Some studies did not provide names of the countries studied, but only mentioned the geographic region (e.g., Europe, Nordic, and Western Europe) or cultural region (e.g., Basque in Lertxundi \& Landeta, 2012) in which the study was conducted. A small number listed the countries with the highest response rates and grouped together those with the lowest, using a catch-all phrase such as 'rest of the world' (e.g., Collings et al., 2010) or 'others' (e.g., Asmussen et al., 2013). While this brevity does not diminish the relevance or contribution of these publications, it nonetheless limits the ability to provide a more precise overview of the geographical foci of the research field to reflect recent FDI activities, although we recognize that for practical reasons, it may not always be possible to provide an exhaustive list.

\section{Insert Table 4 about here}

For the home countries studied, it is clear that existing research has gravitated around MNCs originated from developed economies, such as USA, Japan, Germany, UK and France, with the top ten countries representing over 75 percent of the total number of studies reviewed. This concentration of home countries is not surprising given that they are not only relatively large economies but also main FDI investing countries. Nevertheless, this pattern also reveals ample opportunities for studies of MNCs of other country of origin, including for example, the BRICS countries and other emerging economies where investment mode may differ and so may management strategies and practices (see below for further discussion).

For the host countries studied, UK and China appear to be the most popular countries for study by some distance. Again, this is perhaps not surprising as they are both favorite FDI destination countries (e.g., UNCTAD, 2017). However, it also reflects to some extent the concentration of IHRM scholarship in the UK and research interest in China. The average 
number of host countries included per study across our sample was 2.8, however, this included outliers with subsidiaries from up to 48 different countries (Gaur et al., 2007). Our analysis also suggests a shift towards less developed economies as the locale of MNC host countries for study. For example, parts of Asia, Central and Eastern European Countries were increasingly examined over the 2005-2009 and 2010-2014 periods. At the same time, research interest in MNC subsidiaries in western European countries has somewhat diminished.

\subsection{Thematic foci}

We categorized the 342 studies according to a number of broadly defined themes in order to identify what have been most studied over the review period (see Table 5). We first recorded the subject matter studied in each paper and then grouped them under the thematic categories for the purpose of analysis. As such, the categorization is inevitably somewhat arbitrary as one subject matter could be allocated in one or another category. When this situation arose, we looked at the theoretical perspective the study used and assigned the study in what we believed would be the most suitable category.

As shown in Table 5, a wide variety of topics have been examined in the 342 studies, ranging from HR policies and practices, strategic HRM, to cultural studies, industrial relations and organizational behavior. Some thematic topics appear to be more favored than others, such as knowledge management (including knowledge transfer and the role of expatriates), staffing (including expatriation), transfer of management/HR practices, and industrial relations. It is important to note that after 15 years of extending the frontier of IHRM research, expatriates and transfer of HR practices are no longer the main foci of HRM in MNC studies (see next main section for more discussion), in that our search of the key word in thematic topics showed that 32 papers were on expatriates and repatriates. However, it should be noted that there is growing interest in expatriate management, including self- 
expatriation, outside the MNC framework (though with HR implications for MNCs), and this body of research has formed a separate strand of literature in IHRM (Authors named withheld here for blind review, 2017).

Although the challenges of securing, retaining and developing highly skilled workers are undoubtedly of great importance, many MNCs remain highly dependent on unskilled ultra-low-cost workers (either directly or via suppliers), and, it could be argued that a focus on the former should not mean a neglect of the latter. Indeed, the ways in which the two very different categories of labor may coexist, or, indeed, in some circumstances make the other viable and possible.

Björkman and Welch (2015) suggested that there was a limited focus on global strategy of organizations and strategy making in IHRM research. Our findings reveal that there has been an increased focus on strategic HRM, and a relative decline in explicit studies in industrial relations. However, if the studies in employee voice and representation (core areas of industrial relations) are taken into account, little change has taken place in the latter. Although it is, of course, very welcome that there is increasing work focusing on the strategic dimensions of HRM (which would suggest that a viable grouping of studies assumes that firms are taking HR strategies seriously), this does necessarily mean that this translates into a better quality of working conditions or organizational outcomes; the evidence of existing research on the latter is very mixed.

As we can see from Table 5, the number of studies on knowledge management and staffing - two main thematic topics in which expatriates have traditionally been the main target for research - have declined in the last five-year period of the review, suggesting that the IHRM research community is broadening its interest to reflect the wide range of management practices in MNCs. The growth in the study of OB topics is noticeable. As mentioned earlier, this may reflect the general trend in the HRM research paradigm that is, 
moving increasingly from functional HRM toward OB topics (Godard, 2014). If this trend continues, then it will have a strong implication for the future research focus of the IHRM field and the advancement of the scholarship in this area, in part because IHRM distinguishes itself from domestic HRM in that MNCs have to grapple with more complex and challenging environment within and outside the organization as well as within and across national borders. Such complexities require multilevel, multisource and multidisciplinary research efforts rather than a microlevel orientation characteristic of OB studies.

\section{Insert Table 5 about here}

\subsection{Main theories used}

As indicated in Table 6, a wide variety of theories have been mobilized by authors to underpin their study of HRM, OB or IR aspects of MNCs (see next section for a summary of main theoretical debates of the field). The majority of the articles (mostly empirical studies) used one (172 articles) or two (78 articles) theories to frame their argument, whereas 37 articles adopted three or more theories to inform their studies. The remainder of the articles (54) are either review articles or articles adopting a grounded theory approach as contributions, and a small number of articles do not contain a theory explicitly. In general, articles that provide a multilevel analysis are more likely to adopt multiple theories because different theories carry different explanatory power on different subject matters and analytical levels. Review articles tend to draw on more theories and adopt a multilevel approach and often produce a conceptual/analytical framework as a result of the review.

Based on their review of IHRM articles published in five selected international business and management journals that are quantitative oriented (see Table 1), Welch and Björkman (2015) argued that macro, exogenous factors have often been ignored in the 
conceptual framework of these IHRM studies that primarily used quantitative methods. Our findings here suggest that it is clear that institutional theories remain a dominant theoretical perspective in that more than one-third of the papers adopt a variation of institutional theories. Almost half of the qualitative case studies utilized an institutional perspective - these studies tend to explore the impact of particular institutional pressures on organizational strategies, practices, structures and/or decisions making. Again, the differences of findings between Welch and Björkman (2015) and our study may reflect the sample size (number of journals and articles) of the two review studies. Resource-based and resource-dependence theories; strategic HRM, psychological theories, and cultural theories are also theoretical choices favored by authors. Although as Table 5 indicates, there has been a relative decline in the volume of work published in the latter category. Institutional analysis, however, encompasses quite a diverse body of literature with radically different underlying theoretical assumptions. Hence, the body of work in this area cannot be taken as indicative of the dominance of a single theoretical paradigm or, even, disciplinary foundation.

In their review of the field of IHRM research, De Cieri et al. (2007) critiqued that the field of IHRM research suffered from a relatively narrow focus on expatriates, as discussed earlier, and a relatively narrow range of theoretical perspectives. They also observed the dominance of the US-centric values in the international business research since the 1980s. Nearly a decade on, our review shows that the field has made considerable progress in terms of broadening its scope of subject matters for research and the mobilization of an expanding range of theoretical perspectives to inform our understanding of pressures confronting MNCs, their strategy, policy and practice, and relationship with various stakeholders. At the same time, there is little doubt that there remains a stronger focus on some categories of worker over others; there remains more focus on relatively senior employees than rank and file. 


\section{Insert Table 6 about here}

\section{Research on HRM in MNCs: The state of key debates}

As partly indicated in Table 6, the substantial body of research on HRM in MNCs thus far has hinged on a few key theoretical debates. In this section, we provide a brief review of these key debates, and propose, in series of tables, areas for potential complementarity and synthesis with the theoretical and applied knowledge base from a range of cognate fields. We also highlight some of the recent developments in labor practices and investment modes and their HR implications as a prelude for the concluding section on research avenues.

\subsection{HRM and the MNC: Country of origin and domicile effects}

Much of the literature on IHRM traditionally centered on an exploration as to whether HR practice in MNCs followed on the dominant model in their country of origin or domicile, or in line with some or other global models.

\subsubsection{Country of origin effects}

Country of origin focused studies suggest that MNCs are traditionally ethnocentric, and will follow on the dominant model in their country of origin (Meardi et al., 2009). Although influential studies from the 1970s onwards (c.f., Zeira \& Harari 1977; Mayrhofer \& Brewster 1996; Ferner, 1997) suggest that the dominant focus was toward ethnocentricity, later work shows that these effects are most pronounced in the case of US MNCs. Other studies indicate that MNCs from other countries of origin are much more flexible (Fenton-O'Creevy et al., 2008).

\subsubsection{Globalization and the standardization of practice}


The literature which proposes that MNCs would help pioneer standardization in line with an emerging global model can be divided into two broad categories. Firstly, there are optimistic and pessimistic approaches to globalization. The optimistic approach suggests that owing to new technologies and regulatory approaches, firms will be strongly impelled to standardization around best practices (Ohmae, 1996); MNCs will seek to disseminate these abroad. The pessimistic approach suggests that the globalization of production regimes and trade has driven a race to the bottom, with the need to compete with ultra-low wage economies forcing down labor standards worldwide (Moody, 1997). Secondly, there are ones that suggest that the liberal market model has attained global ecosystem dominance, gradually eroding other types of capitalism (Schneider \& Paunescu, 2012). As major international actors, MNCs are likely to be well attuned to such trends, and indeed, may actively seek to drive them forward, reflecting the pressures imposed on them in turn through activist investors (c.f., Tihanyi et al., 2003). In terms of HR practice, this will involve the dissemination of hard HRM strategies, characterized by contingent employment contracts and reward systems, and anti-union policies (Tihanyi et al., 2003). On the one hand, even hightech MNCs from liberal markets have become quite aggressive in seeking to source cheaper labor abroad, even in the case of key design functions. On the other hand, there is a great deal more to FDI choices than simply cheap labor. Notably, MNCs from other countries of origin (both coordinated and emerging markets) often follow very different logics (Lane, 1998). Nonetheless, it is generally recognized that MNCs can exert a profound effect on labor standards, and this is often not benign (Buckley \& Ghauri 2004).

\subsubsection{Country of domicile effects}

Alternatively, there is the literature on country of domicile effects. Again, this literature can be divided into two sub-categories (Brewster et al., 2008). The first is the literature which 
focuses on the effects of country of domicile cultural dynamics, although, in turn, there is some debate as to whether national cultures can be categorized according to objective measures, for example, as per Hofstede's $(1980 ; 1991)$ well known comparative taxonomies of cultures. The latter was an approach that was particularly influential in the comparative HRM literature of the 1990s (e.g., Evans \& Lorange 1990; Tayeb 1995). Critics have charged that Hofstede's approach (and other similar national cultural taxonomies) has a very thin empirical base, and indeed, can be considered pseudo-scientific in that it makes quite firm claims of the social condition based on assumptions that might be refuted (McSweeney, 2002). A further limitation is the strong implicit assumption of path dependency. In Hofstede's defense, it could be argued that the cultural categories promulgated point to a fundamental underlying truth: national cultures do differ, and this will impact organizational life. This would account for the persistent influence of this approach, and indeed, its continued dominance.

In contrast to such etic approaches, emic approaches suggest that culture is subjective, not readily categorized, and can only be understood from an insider's point of view (e.g., Morris et al., 1999; Tsui, 2004). This assumption informs anthropological approaches to comparative analysis of workplace dynamics (see Comaroff \& Comaroff, 2002), but owing to the elusiveness of an accurate base of comparison has only had limited influence in the comparative HRM literature. Rather, it has been most influential in diluting, qualifying or supplementing the comparative statics of etics.

The second strand of literature on domicile effects broadly focuses on institutions. A problem with institutional analysis is that there is often a tendency to conflate very different approaches to understanding institutional effects, ranging from the sociological approach of Di Maggio and Powell (1983), to the socio-economic approach of writers such as Whitley (1999) and Hall and Soskice (2001), to orthodox economic approach of writers such as La 
Porta et al. $(1997 ; 1998)$. What this disparate literature has in common is that the assumption that owing to formal incentives and informal pressures, firms have strong incentives to conform to dominant recipes of practice. Where the literature diverges is on the relative importance of informal ties and networks (Hall \& Soskice, 2001), the relative desirability of a single institutional regime (La Porta et al., 1997; 1998), and the nature and causes of institutional change (c.f. Hall \& Soskice, 2001; Wood et al., 2014).

Underlying such approaches is a fundamental tension. If the firm is seen as socially embedded, with internal organizational practice at least in part a function of the nature and density of formal and informal ties and conventions linking the firm to other stakeholders, then country of domicile effects are paramount. Yet, if institutions play a dominant role in shaping corporate governance regimes, and whether the primary focus of the latter drives the firm towards maximizing shareholder value or not, then the location of headquarters is of particular importance, and, indeed, will over-ride any country of domicile effects. However, this does not mean that institutional approaches cannot encompass in their analysis aspects of culture. Indeed, influential approaches to cross-cultural analysis do grapple with some of the same broad questions as institutional accounts: the persistence of national differences and why national contexts have evolved in the manner they did.

\subsubsection{Country of origin and domicile effects, and comparative institutional analysis}

It might be expected that the explicitly comparative socio-economic strand of institutional thinking might be particularly dominant in understanding how MNCs cope with different regulatory regimes, given its strong emphasis on the relationship between regulation, and relative stakeholder resource allocations and well-being. However, much of the work on the topic has tended to neglect MNCs. Indeed, the influential 2001 Hall and Soskice collection made little mention of MNCs at all. Only recently, and drawing on the business systems 
theory sub-school of analysis, have writers such as Whitley (2007) and Morgan (2012) sought to systematically explain the role of MNCs from a comparative institutional perspective. They argue that, as they straddle institutional regimes, MNCs are subject to competing institutional pressures from each, and they will attempt to reconcile them through compromises (Ferner et al., 2005; Ferner et al., 2011; Morgan, 2012; Wood \& Lane, 2012). Again, MNCs enter into national markets because of the particular advantages they incur. This will include their ability to access a particular production regime, which, in turn, is supported by both national regulation and informal conventions and understandings (Morgan \& Kristensen, 2006; Morgan, 2012). Given this, they will have strong incentives to support existing arrangements, or at best, limited reforms that uphold the key features that they desire (Morgan, 2012). Recent empirical work based on comparative survey evidence seems to confirm these points, suggesting that MNCs may accordingly tend to follow national firms, rather than pioneering new paradigms (c.f., Brewster et al., 2008; 2016).

\subsubsection{Developments in theory and synthesis}

One of the main limitations of comparative institutional approaches - and, indeed, crosscultural studies - was a focus on stylistic ideal types, backed up with recourse to macro level economic data, broad societal indices, and limited panels of case study evidence (Wood et al., 2014). Yet, institutional HRM is ultimately about what goes on the firm. Hence, its insights have a great deal to offer to the literature on comparative institutional analysis, even if a counterpoising weakness in the 'comparative HRM' and 'HRM in MNCs' literatures has been a detailed focus on firm practices, tracing somewhat vague and indeterminate lines back to very loose summaries of societal features. Here, a key research agenda is seeking to more closely draw out the links between settings, competing contextual pressures (local, global, country of origin), and specific sets of practices. Recent comparative institutional work has 
highlighted the extent to which national institutional orders are quite durable, with some key features persisting and indeed strengthening as others are being discarded (Lane \& Wood 2009; Witt et al., 2017). This would suggest that rather than composite and indivisible societal wide bundles of rules translating into bundles of firm level practices, there are quite clear lines of causality between specific institutional features and specific sets of practices. Hence, complementarity may be a great deal more confined and represent as much coping as systematic building on strengths, highlighting the need for closer analysis of firm level evidence (Crouch et al., 2005; Lane \& Wood, 2009). If the literature on comparative institutional analysis concentrates on societal features, and only accords limited and somewhat stylized attention to intra-organizational practice (Wood et al. 2014), the literature on IHRM has tended to be somewhat light on the variable consequences of different national regulatory features. We argue that there is a need for comparative institutional analysis to develop its firm level evidence base, and IHRM to accord more detailed attention to regulation, and hence, the opportunities for closer synthesis between these two areas of enquiry, allowing each body of knowledge to supplement the other providing a more holistic account.

\subsection{Expatriates and the MNC}

As mentioned earlier, much of the early literature on IHRM concentrated on the practicalities of expatriate management in the MNC context (e.g., Brewster \& Suutari, 2005; Brewster \& Scullion, 2007; Howe-Walsh \& Schyns, 2010). This included issues of career planning (Scullion \& Brewster 2002; Brewster \& Scullion, 2007), relations with local staff (Brewster \& Harris, 1999; Hechanova et al., 2003), and the challenges of relocation (Brewster \& Suutari, 2005) and return to the country of origin (Baruch \& Altman, 2002; Baruch et al., 2002). Expatriate working may provide an incumbent with exposure to a wider cross section 
of organizational activities, enable a better standard of living and/or a pay premium, and/or enable insights and experiences (Kamoche, 1997; Minbaeva \& Michailova, 2004). At the same time, it may bring the risk of being moved to the organizational periphery, slower career progression than at the $\mathrm{HQ}$, and strain on established relationships and family life (Brewster \& Harris, 1999; Brewster \& Suutari, 2005).

However, up until recently, the bulk of the literature on this topic has tended to focus on highly skilled categories of labor. Yet, the bulk of expatriate workers for MNCs are third party/country nationals occupying semi- and unskilled positions. Most prominent are the large numbers of south and east Asian expatriate workers within petro states, most notably in the Gulf, but also further afield, such as Brunei (see also research avenues section below). There is a growing body of work on this category of labor, which is scattered across area studies and development journals, in addition to work and employment ones (see Abella, 1995; Longva, 1999; Jureidini, 2005; Budhwar \& Mellahi, 2006; Lee, 2009; Cooke, 2014). Common themes emerging are the usage of highly segmented labor markets, and the range of human rights and ethical issues involved in the usage of unskilled expatriate labor. Typically, parent or highly skilled third country nationals occupy the most senior positions. Indigenous staff are concentrated in relatively highly paid managerial positions, but fulfill roles that, at times, have been criticized as window-dressing necessary to satisfy local elites (see Budhwar \& Mellahi, 2006; Mellahi, 2007). Thirdly, menial and unskilled positions are fulfilled by third country nationals, typically from developing countries with high poverty rates. Local legislation often leaves such workers rightless, and bound to employers (Cammett \& Posusney, 2010); in the worst instances, this may also entail the routine confiscation passports and outright forced labor (Lerche, 2007). MNCs may seek abrogate their responsibilities through the usage of labor brokers or sub-contractors; however, ultimately, the work done is explicitly 
commissioned by the firm to carry out a range of operational and support tasks within the organization, and as such, responsibility cannot be completely abrogated.

A relatively recent development has been the large-scale usage by Chinese MNCs of unskilled and semi-skilled country of origin nationals to staff acquired firms, start-ups or (construction) project work in Africa and other Asian countries, largely to overcome regulatory, language and cultural constraints and to alleviate labor/skill shortage problems (e.g., Lee, 2009; Mohan \& Tan-Mullins, 2009; Cooke \& Lin, 2012). Examples would range from mining MNCs in Zambia, construction MNCs in Namibia, and mining multinational small businesses in Ghana. On the one hand, this lowers transaction costs, simplifies the standardization of HR practices, and facilitates communication. On the other hand, this may create tensions with remaining existing indigenous staff and communities, and raise debates as the value of attracting FDI that does not secure existing jobs or provide new ones (Mohan \& Tan-Mullins, 2009; Gadzala, 2010; Giese \& Thiel, 2014). This, and the demographic implications in the case of the very large-scale transshipment of labor, has led to intense political controversies, which have included the election of a government on an explicitly anti-Chinese ticket (Zambia) and wholesale programs (Ghana) (see Negi, 2008). Much of the research on the usage of such semi- and unskilled expatriates may be found in the development and area studies literatures, again, which may supplement the IHRM literature and open opportunities for synthesis.

\section{Discussion and avenues for future research}

The above analysis confirmed both the detailed knowledge bases and boundaries in terms of what we know on expatriates, on contextual effects, and on flows of knowledge and strategy. It also confirmed the importance of extending the scale and scope of IHRM, drawing on the knowledge base and insights of cognate fields. In the process of reviewing these fields of 
studies, we revealed research gaps in terms of methods, locale of studies, types of employees /stakeholders studied, thematic foci, and theoretical engagement. In this section, we consolidate our analysis and arguments thus far and further highlight a number of related avenues for future dialogue and synthesis to advance the research of HRM in MNCs. Given the fact that previous IHRM reviews, for example, De Cieri et al. (2007), Schuler and Tarique (2007), Björkman and Welch (2015), Welch and Björkman (2015), and Brewster et al. (2016) have provided a substantive list of research avenues respectively, we will not repeat areas that have been covered. Instead, we focus on the broader aspects that have been less well explored but are deemed important in advancing our knowledge in the field.

Firstly, at a theoretical and thematic level, the IHRM literature on country of origin and domicile effects could benefit greatly from recent developments and extensions of comparative institutional analysis, whilst the latter could equally benefit from the IHRM literature. Existing thematic foci as summarized in Table 5 suggest that there remains limited research attention on certain HRM aspects. One is that the role of corporate social responsibility as part of IHRM is relatively neglected (e.g., Cooke et al., 2017). Yet, best practices represent not only the product of context, but also of the choices of owners, often prompted by profit, but sometimes by genuine altruism. A second aspect is that the flow of knowledge and the imposition of HR strategy is not confined to organizational boundaries (or even within the confines of the owner managerial relationship), but also may extend to suppliers and contractors, through outsourcing and/or the usage of shared services. Finally, there is much more work on the relationship between central management and expatriate workers, than on the quotidian dynamics of the interaction between expatriates and locals, and how the latter affect and are affected by the former. Specifically, the IHRM literature on expatriates could greatly benefit from drawing on the theoretical and applied insights afforded by the development and area studies literature on the usage of semi and unskilled expatriates 
(from third country) and vice versa. Research in this direction may draw on the world systems theory, amongst others, and link this knowledge to the 'race to the bottom' debate (e.g., Davies and Vadlamannati, 2013).

Secondly, in terms of the economic geography (i.e., not just geographic locale) of MNC studies, extant research has relied mainly on large and traditional MNCs from developed economies, many of whom prestigious ones, as research sites. Newer forms of FDI and locales are underrepresented in extant literature. For example, countries with large Export Processing Zones - further to China - such as Bangladesh, Mexico, Sri Lanka, and Vietnam would warrant further (critical) examination. These economic zones are often subjected to separate regulation, exempted from local labor laws, and enable a preference of internal over external regulation (Mosley \& Uno 2007). As Buckley (2014, p. 239) argued in his 'economic geography' thesis, cities, rather than countries, are the fierce competitors as FDI recipients, and may indulge MNCs with attractive investment conditions, including reduced labor standards. This in turn would warrant a critical scrutiny of the HR policies and practices that MNCs utilize in relation to local and third country national employees in particular.

In addition, our dataset contains limited research on one of the most disruptive phases of capitalism, the global financial crisis/global recession, whereby neither the implications nor consequences of HR policies and practices during or post this episode of disruptive change for MNCs was explored. Nor has the impact of the period of austerity in the European context on MNC subsidiaries in other (economic) regions been assessed. We would contend that this is a missed opportunity, although we are acutely aware of the immense challenges faced by researchers to conduct research into these sensitive and dynamic phenomena and that our data cut of point was 2014, which means that the latest research on these topics, if any, was not captured in our analysis. 
Thirdly, research on HR strategies and practices of Japanese MNCs has been an integral aspect of management, industrial and human relations research for much of the $20^{\text {th }}$ and $21^{\text {st }}$ century (e.g., Dore, 1973; Katz \& Darbishire, 2000; Hall \& Soskice, 2001). However, MNCs from non-western and emerging economies - including, but not exclusively the BRICS - have not received the same volume of scholarly attention (Cooke et al., 2015). Our dataset suggests that only 22 of the 342 studies include emerging MNCs, mainly from China and India (most of which were published in the 2005-2014 period). Given the strong possibility that FDI from BRICS countries will continue to grow, with MNCs as the main vehicles, a stronger momentum in researching on emerging MNCs may be developed to shed light on their business activities, management challenges they may encounter, their position and voice in the global economy vis-à-vis more powerful and established MNC competitors, and how this competition may undermine or enhance emerging MNCs' international image and ability to attract and retain talent and their broader HR strategy. Related to this topic would be the strong potential of examining the motives and strategies of firms from emerging economies in developing their international footprints rapidly through international joint ventures and cross-border acquisitions. For example, in the case of China, how such a rapid expansion and its HR strategy and practice may be underpinned by the liability of emergingness' (Madhok \& Keyhani, 2012, p. 26) and liability of Chineseness due to the state connection of many internationalizing Chinese firms.

Fourthly, the IHRM literature accords a strong attention to intra-organizational knowledge flows and the relative dissemination of core strategies. However, there may be flows of knowledge, and the imposition of new strategies from outside the firm, a process that, itself may span national boundaries. Even indigenous firms may be affected from investors from abroad. In particular, there has been growing concern as to the effects of alternative foreign investors - private equity and sovereign wealth funds (SWF) - on work 
and employment within the firms they target. The body of comparative corporate governance research evidence in this area is more limited. Some studies suggest that alternative investors may have limited or positive effects on employees and argue that alternative investors may provide new knowledge and impart potentially beneficial fresh strategic directions (e.g., Bruton et al., 2010). However, other work points to strong country-of-origin effects in the case of private equity from the developed liberal markets, and this is associated with reduced job security and proclivity to invest in people (Guery et al., 2016).

In the case of sovereign wealth funds, the evidence base is even more limited. Recent research on the Norwegian Sovereign Wealth Fund (the Government Pension Fund-Global) an investor with an explicitly ethical brief - indicates positive outcomes for jobs (Goergen et al., 2016). Looking at Gulf SWF investments in Germany, Haberly (2014) found that they appear to have contributed to shoring up the traditional German model of corporate control and associated firm level practices. However, a study by Gospel and Pendleton, looking at Gulf SWF investments in the UK, found more limited effects, and, in at least one instance, adverse consequences for pensions (Gospel \& Pendleton, 2014a; 2014b). As alternative investors (e.g., Sovereign Wealth Funds, Private Equity, and Hedge Funds) have become more prominent, there is little doubt that there is need for much more work on investor country of origin on HR practices, supplementing the traditional focus on head office effects. This would supplement the growing body of work on comparative corporate governance which concentrates on investor effects on performance, but which only recently has started to take account of HR issues (Guery et al., 2016). Again, this might open the way to future transdisciplinary dialogue and syntheses.

Fifthly, there is the impact of technology. Technology tends to have foreseen and unforeseen consequences (Hall \& Martin, 2005) and is socially embedded; this will result in variations in the take up of technologies and potentially result in both divergence and 
convergence in HRM practices between settings. For example, on the one hand, robotics has the potential to displace workers from even quite highly skilled jobs. On the other hand, within liberal market economies such as the US and the UK, labor has become so cheap as to displace machinery even in areas of technological maturity, an example being the ousting of automatic car washes by hand ones (Clark \& Colling, 2017). Again, virtual working may make employment more accessible and facilitate in better work life balances, as well as enabling firms to make usage of genuinely global labor forces (Lipnack \& Stamps, 2008). However, it will also result in reduced inter personal contact, making informal communication and the sharing of ideas, and the building of shared organizational identities, much more difficult, and repressive systems of monitoring and control easier (Jackson et al., 2006). In turn, this could potentially make for more fragmented organizations, even as their scale and scope can be greatly increased.

Sixthly, if economics, socio-economics and economic geography have influenced IHRM studies, it could be argued that the sociological and psychological traditions have not had quite the same influence as in the literature dealing with single countries and nation specific firms. In terms of sociology, there remains a need to better understand the differences and common ground between micro-theories best suited to understanding internal organizational dynamics and those focusing on contextual features and differences. For example, although they are often conflated, there is more room for systematic comparisons between, and, indeed for a new wave of theorizing encompassing, the micro-sociological approaches to institutions (Di Maggio \& Powell, 1983; Hallett \& Ventrasca, 2006) and the macro-level socio economic tradition. Again, in understanding the effects of culture, the same would hold for the social anthropology tradition, that focuses on local constructions and manifestations of culture, macro-sociological conceptualizations of culture, and indeed, applied comparative accounts of culture (Hofstede, 1980). Pychological approaches to 
understanding decision making and behavioral patterns within contexts (Donaldson \& Ko, 2010; O'Reilly \& Chatman, 1986) might be compared with those that see the predominant variations as being between, rather than within nations (Hall \& Soskice 2001; Brewster et al. 2006). This is not simply an issue of structure impacting on action and vice versa (Giddens, 1984), but also how different modes of behavior coexist and influence each other on a horizontal basis, and, indeed, how developments in the economic and natural environment are accommodated on a range of different planes.

\section{Conclusions}

This study reviewed the state of knowledge on HRM in MNCs over the 15-year period in major business and management journals in English. It revealed patterns of research sites, research methods used, topical foci and theoretical orientations. It argues that there are quite fundamental issues and trends - the rise of emerging market MNCs, transnational emerging investors, and unskilled and semi-skilled expatriates (from third countries) - that need to be more fully taken account of in extending the literature. Although there is already a growing body of work on the former, this literature has tended to focus on Chinese, and to a lesser extent, Indian MNCs, when it is apparent that MNCs from other emerging markets may follow quite different approaches to HRM. This paper provides both a review of the existing state of knowledge, and highlights ways in which it can be linked, and extended to deal with such developments more fully. In other words, it seeks to both provide a foundation of salient literature as a basis for developing enquiries into current issues and highlight key possible research agendas for examining the latter.

We argue that there is a pressing need for more holistic accounts on the role of HRM in the MNC, drawing on insights afforded by cognate fields. This would suggest the need for more integrated approaches to understand how very different types of staffing policy may 
coexist, and the different needs of many very different kinds of expatriate worker. The relative position of each sub-category of the latter would in turn reflect institutional arrangements in both the firm's country of origin and where the work actually takes place. Again, although a focus on country-of-origin effects would capture effects of relative owner and stakeholder rights on overall corporate direction, national institutional regimes may project their effects abroad in other ways, most notably through investors whose activities cross national boundaries: the rise of alternative investors such as sovereign wealth funds and private equity makes this an increasingly pressing area of enquiry, even if it has received little attention to date in the international and comparative HRM literature. Such investors may impart knowledge and impose strategy, just as the latter two flow across MNCs from headquarters to countries of domicile. This highlights the extent to which the three key concerns of contemporary IHRM research are implicitly closely interlinked; whilst each area may be developed and extended through recourse to insights from cognate fields, there is also room for a more systematic approach to integrating and synthesizing the different bodies of IHRM research. If these two endeavors were combined, there is much potential for further advancing the field, and placing it more centrally within business and management studies and broader socio-economic research.

We therefore conclude that major developments on the ground - the increasing numbers of unskilled expatriate workers, the rise of MNCs from emerging markets, including beyond the BRICs, and the increasing prominence of transnational alternative investors have the potential to transform the field of enquiry, yet are only starting to appear in the IHRM literature: in developing these major areas of enquiry, it is important to draw on insights from cognate fields and through extending the literature on comparative institutional analysis to take fuller account of trans-national actors. It is hoped that the consolidation of the existing literature provided in this paper may serve as a foundation for such endeavors. 
Finally, a number of limitations exist in this study. First, our search might not have located each and all academic journal articles relevant to IHRM published in English. Nonetheless, we are confident that our search has captured the bulk of the studies on the topic and our analysis is aimed at identifying a broad pattern instead of generating a precise picture. Second, this study only focused on literature published in English, which means that our analysis has not been informed by relevant studies published in non-English journals. 


\section{References}

Abella, M. I. (1995). Asian migrant and contract workers in the Middle East. In Cohen. R. (eds), The Cambridge Survey of World Migration. Cambridge, England: Cambridge University Press, 418-423.

Asmussen, C. G., Foss, N. J., \& Pedersen, T. (2013). Knowledge transfer and accommodation effects in multinational corporations: Evidence from European subsidiaries. Journal of Management, 39(6), 1397-1429.

Bailey, M. (2009). Can you hear us? The effectiveness of European Works Councils as a mechanism of employee voice for Hungarian workers of PrintCo. Employee Relations, 31(2), 197-218.

Barry, B. \& Wilkinson, A. (2015). Pro-social or pro-management? A critique of the conception of employee voice as a pro-social behaviour within organizational behaviour. British Journal of Industrial Relations, 54(2), 261-284.

Baruch, Y. \& Altman, Y. (2002). Expatriation and repatriation in MNCs: A taxonomy. Human Resource Management, 41(2), 239-259.

Baruch, Y., Steele, D. J., \& Quantrill, G. A. (2002). Management of expatriation and repatriation for novice global player. International Journal of Manpower, 23(7), 659671.

Björkman, I. \& Welch, D. (2015). Framing the field of international human resource management research. International Journal of Human Resource Management, 26(2), $136-150$.

Brewster, C. \& Harris, H. (1999). International Human Resource Management: Contemporary Issues in Europe. East Sussex, UK: Psychology Press. 
Brewster, C., Mayrhofer, W., \& Smale, A. (2016). Crossing the streams: HRM in multinational enterprises and comparative HRM. Human Resource Management Review, 26(4), 285-297.

Brewster, C. \& Scullion, H. (2007). A review and agenda for expatriate HRM. Human Resource Management Journal, 7(3), 32-41.

Brewster, C. \& Suutari, V. (2005). Global HRM: Aspects of a research agenda. Personnel Review, 34(1), 5-21.

Brewster, C., Wood, G. \& Brookes, M. (2008). Similarity, isomorphism or duality? Recent survey evidence on the human resource management policies of multinational corporations. British Journal of Management, 19(4), 320-342.

Brewster, C., Wood, G., Brookes, M., \& Ommeren, J. V. (2006). What determines the size of the HR function? A cross-national analysis. Human Resource Management, 45(1), 321.

Bruton, G. D., Filatotchev, I., Chahine, S., \& Wright, M. (2010). Governance, ownership structure, and performance of IPO firms: The impact of different types of private equity investors and institutional environments. Strategic Management Journal, 31(5), 491509.

Bryman, A. \& Bell, E. (2015). Business Research Methods, 4th edn. Oxford: Oxford University Press.

Bryson, A. (2004). Managerial responsiveness to union and non-union voice in Britain. Industrial Relations, 43(1), 213-241.

Buckley, P. J. \& Ghauri, P. N., (2004). Globalisation, economic geography and the strategy of multinational enterprises. Journal of International Business Studies, 35(2), 81-98.

Buckley, P. (2014). Forty years of internalization theory and the multinational enterprise. Multinational Business Review, 22(3), 227-245. 
Budhwar, P. S. \& Mellahi, K. (2006). Managing Human Resources in the Middle East. London, UK: Routledge.

Cammett, M. \& Posusney, M. P. (2010). Labor standards and labor market flexibility in the Middle East: Free trade and freer unions? Studies in Comparative International Development, 45(2), 250-279.

Cappelli, P. (2008). Talent on Demand - Managing Talent in an Age of Uncertainty. Boston: Harvard Business Press.

Clark, I. \& Colling, T. (2017). Work in Britain’s informal economy: Learning from road $\square$ side hand car washes. British Journal of Industrial Relations, DOI: 10.1111/bjir.12286 Early online at: http://onlinelibrary.wiley.com/doi/10.1111/bjir.12286/full.

Collings, D. G., McDonnell, A., Gunnigle, P., \& Lavelle, J. (2010). Swimming against the tide: Outward staffing flows from multinational subsidiaries. Human Resource Management, 49(4), 575-598.

Comaroff, J. \& Comaroff, J. (2002). Alien-nation: Zombies, immigrants, and millennial capitalism. South Atlantic Quarterly, 101(4), 779-805.

Cooke, F. L. (2014). Chinese multinational firms in Asia and Africa: Relationships with institutional actors and patterns of HRM practices. Human Resource Management, 53(6), 877-896.

Cooke, F. L. \& Lin, Z. (2012). Chinese firms in Vietnam: Investment motives, institutional environment and human resource challenges. Asia Pacific Journal of Human Resources, 50(2), 205-226.

Cooke, F. L., Veen, A., \& Wood, G. (2017). What do we know about cross-country comparative studies in HRM? A critical review of literature in the period of 2000-2014. The International Journal of Human Resource Management, 28(1), 196-233. 
Cooke, F. L., Wood, G., \& Horwitz, F. (2015). Multinational firms from emerging economies in Africa: Implications for research and practice in human resource management. International Journal of Human Resource Management, 26, 2653-2675.

Crouch, C., Streeck, W., Boyer, R., Amable, B., \& Hall, P. A. (2005). Dialogue on 'Institutional complementarity and political economy'. Socio-Economic Review, 3(2), $359-382$.

Dalton, K., \& Druker, J. (2012). Transferring HR concepts and practices within multi-national corporations in Romania: The management experience. European Management Journal, $30(6), 588-602$.

Davies, R. B., \& Vadlamannati, K. C. (2013). A race to the bottom in labour standards? An empirical investigation. Journal of Development Economics (103), 1-14.

De Cieri, H., Cox, J. W., \& Fenwick, M. (2007). A review of international human resource management: Integration, interrogation, imitation. International Journal of Management Reviews, 9(4), 281-302.

Deutsch, M. (1973). The resolution of conflict. New Haven: Yale University Press.

Di Maggio, P. \& Powell, W. (1983). The iron cage revisited - Institutional isomorphism and collective rationality in organizational fields. American Sociological Review, 48(2), $147-160$.

Donaldson, S. I. \& Ko, I. (2010). Positive organizational psychology, behavior, and scholarship: A review of the emerging literature and evidence base. The Journal of Positive Psychology, 5(3), 177-191.

Dore. R. (1973). British Factory-Japanese Factory: The Origins of National Diversity in Industrial Relations. London, UK: George Allen \& Unwin Ltd.

Dunning, J. H. (1975). Economic Analysis and the Multinational Enterprise. New York: Praeger 
Dunning, J. H. (1988). Explaining International Production. London: Unwin Hyman Inc.

Edwards, T. \& Rees, C. (2016). International Human Resource Management: National Systems and Multinational Companies, 3rd edn. USA: Pearson Higher Education.

Evans, P. \& Lorange, P. (1990). The two logics behind human resource management. In Doz Y. \& Laurent, A. (eds), Human Resource Management in International Firms. London, UK: Palgrave Macmillan, 144-161.

Fenton-O'Creevy, M., Gooderham, P., \& Nordhaug, O. (2008). Human resource management in US subsidiaries in Europe and Australia: Centralization or autonomy? Journal of International Business Studies, 39(1), 151-166.

Ferner, A. (1997). Country of origin effects and HRM in multinational companies. Human Resource Management Journal, 7(1), 19-37.

Ferner, A., Almond, P., \& Colling, T. (2005). Institutional theory and the cross-national transfer of employment policy: The case of 'workforce diversity' in US multinationals. Journal of International Business Studies, 36(3), 304-321.

Ferner, A., Edwards, T., \& Tempel, A. (2011). Power, institutions and the cross-national transfer of employment practices in multinationals. Human Relations, 65(2), 163-187.

Foucault, M. (1991). Discipline and Punishment: The Birth of the Prison. Harmondsworth: Penguin.

Freeman, R., Boxall, P., \& Haynes, J. (2007). What Workers Say. Ithaca: ILR Press.

Gadzala, A. W. (2010). From formal- to informal-sector employment: Examining the Chinese presence in Zambia. Review of African Political Economy, 37(123), 41-59.

Gaur, A. S., Delios, A., \& Singh, K. (2007). Institutional environments, staffing strategies, and subsidiary performance, Journal of Management, 33(4), 611-636.

Giddens, A. (1984). The Constitution of Society: Outline of the Theory of Structuration. Berkeley: University of California Press. 
Giese, K. \& Thiel, A. (2014). The vulnerable other-distorted equity in Chinese-Ghanaian employment relations. Ethnic and Racial Studies, 37(6), 1101-1120.

Godard, J. (2014). The psychologization of employment relations? Human Resource Management Journal, 24(1), 1-18.

Goergen, M., O'Sullivan, N., Wood, G., \& Baric, M. (2016). Sovereign wealth funds, productivity and people: The impact of Norwegian government pension fund - global investments in the UK. Working paper, University of Essex.

Goffman, E. (1956). The Presentation of Self in Everyday Life. Edinburgh: University of Edinburgh.

Gospel, H. \& Pendleton, A. (2014a). Financialization, new investment funds and labor. In Gospel, H., Pendleton, A., \& Vitols, S. (eds), Financialization, New Investment Funds and Labor: An International Comparison. Oxford: Oxford University Press, 1-52.

Gospel, H. \& Pendleton, A. (2014b). Financialization, new investment funds and weakened labor: The case of UK. In Gospel, H., Pendleton, A. \& Vitols, S. (eds), Financialization, New Investment Funds and Labor: An International Comparison. Oxford: Oxford University Press, 86-114.

Grant, R. M. (1996). Toward a knowledge-based theory of the firm. Strategic Management Journal, 17(S2), 109-122.

Guery, L., Stevenot, A., Brewster, C., \& Wood, G. (2016). The impact of private equity on employment: The consequences of fund country of origin - New evidence from France. Industrial Relations: A Journal of Economy and Society, 56(4), 723-750.

Haberly, D. (2014). White knights from the gulf: Sovereign wealth fund investment and the evolution of German industrial finance. Economic Geography, 90(3), 293-320. 
Hall, J. K. \& Martin, M. J. (2005). Disruptive technologies, stakeholders and the innovation value $\square$ added chain: a framework for evaluating radical technology development. R\&D Management, 35(3), 273-284.

Hall, P. \& Soskice, D. (2001). An introduction to the varieties of Capitalism. In Hall, P. \& Soskice D. (eds), Varieties of Capitalism: The Institutional Foundations of Competitive Advantage. Oxford: Oxford University Press, 1-70.

Hallett, T. \& Ventresca, M. J. (2006). Inhabited institutions: Social interactions and organizational forms in Gouldner's Patterns of Industrial Bureaucracy. Theory and Society, 35(2), 213-236.

Harley, B. (2015). The one best way? 'Scientific' research on HRM and the threat to critical scholarship. Human Resource Management Journal, 25(4), 399-407.

Harzing, A. W. (1999). Managing the Multinationals: An International Study of Control Mechanisms. Cheltenham: Edward Elgar.

Hechanova, R., Beehr, T. A., \& Christiansen, N. D. (2003). Antecedents and consequences of employees' adjustment to overseas assignment: A meta-analytic review. Applied Psychology, 52(2), 213-236.

Hirschman, A. (1970). Exit, Voice and Loyalty. Cambridge, MA: Harvard University Press.

Hofstede, G. (1980). Culture's Consequences: International Differences in Work-Related Values. Beverly Hills: Sage.

Hofstede, G. (1991). Cultures and Organizations. London: McGraw-Hill.

Howe-Walsh, L. \& Schyns, B. (2010). Self-initiated expatriation: Implications for HRM. International Journal of Human Resource Management, 21(2), 260-273.

Hymer, S. H. (1976). The International Operations of National Firms: A Study of Foreign Direct Investment. Cambridge: MIT Press. 
Jackson, P., Gharavi, H. \& Klobas, J. (2006). Technologies of the self: Virtual work and the inner panopticon. Information Technology \& People, 19(3), 219-243.

Jureidini, R. (2005). Migrant workers and xenophobia in the Middle East. In Bangura, Y. \& Stavenhagen R. (eds), Racism and Public Policy. UK: Palgrave Macmillan, 48-71.

Kamoche, K. (1997). Knowledge creation and learning in international HRM. International Journal of Human Resource Management, 8(2), 213-225.

Katz, H. C. \& Darbishire, O. (2000). Converging Divergences: Worldwide Changes in Employment Systems. Cornell, USA: Cornell University Press.

Lane, C., (1998). European companies between globalization and localization: a comparison of internationalization strategies of British and German MNCs. Economy and Society, 27(4), 462-485.

Lane, C. \& Wood, G. (2009). Diversity in Capitalism and Capitalist Diversity. Economy and Society, 38(4), 531-551.

Lavelle, J., Gunnigle, P., \& McDonnell, A. (2010). Patterning employee voice in multinational companies. Human Relations, 63(3), 395-418.

La Porta, R., Lopez-de-Silanes, F., Shleifer, A., \& Vishny, R. M. (1997). Legal determinants of external finance. Journal of Finance, 52(3), 1131-1150.

La Porta, R., Lopez-de-Silanes, F., Shleifer, A., \& Vishny, R. M. (1998). Law and finance. Journal of Political Economy, 106(6), 1113-1155.

Lee, C. K. (2009). Raw encounters: Chinese managers, African workers and the politics of casualization in Africa's Chinese enclaves. China Quarterly, 199, 647-666.

Lerche, J. (2007). A global alliance against forced labor? Unfree labor, neo-liberal globalization and the international labor organization. Journal of Agrarian Change, 7(4), $425-452$. 
Lertxundi, A., \& Landeta, J. (2012). The dilemma facing multinational enterprises: Transfer or adaptation of their human resource management systems. International Journal of Human Resource Management, 23(9), 1788-1807.

Lipnack, J. \& Stamps, J. (2008). Virtual Teams: People Working across Boundaries with Technology. John Wiley \& Sons.

Longva, A. N. (1999). Keeping migrant workers in check: The Kafala system in the Gulf. Middle East Report, 211, 20-22.

Lukes, S. (1975). Power: A Radical View. London: Palgrave-Macmillan.

Madhok, A., \& Keyhani, M. (2012). Acquisitions as entrepreneurship: Asymmetries, opportunities, and the internationalization of multinationals from emerging economies. Global Strategy Journal, 2(1), 26-40.

Mayrhofer, W. \& Brewster, C. (1996). In praise of ethnocentricity: Expatriate policies in European multinationals. International Executive, 38(6), 749-778.

McSweeney, B. (2002). Hofstede's model of national cultural differences and their consequences: A triumph of faith - a failure of analysis. Human Relations, 55(1), 89118.

Meardi, G., Marginson, P., Fichter, M., Frybes, M., Stanojević, M., \& Toth, A. (2009). Varieties of multinationals: Adapting employment practices in Central Eastern Europe. Industrial Relations, 48(3), 489-511.

Mellahi, K. (2007). The effect of regulations on HRM: Private sector firms in Saudi Arabia. International Journal of Human Resource Management, 18(1), 85-99.

Minbaeva, D. B., \& Michailova, S. (2004). Knowledge transfer and expatriation in multinational corporations: The role of disseminative capacity. Employee Relations, 26(6), 663-679 
Mohan, G. \& Tan-Mullins, M. (2009). Chinese migrants in Africa as new agents of development? An analytical framework. European Journal of Development Research, 21(4), 588-605.

Moody, K. (1997). Workers in a Lean World. London: Verso.

Morgan, G. (2012). International business, multinationals and national business systems. In Wood, G. \& Demirbag, M. (eds), Handbook of Institutional Approaches to International Business. Cheltenham: Edward Elgar, 18-40.

Morgan, G. \& Kristensen, P. (2006). The contested space of multinationals: Varieties of institutionalism, varieties of capitalism. Human Relations, 59(11), 1467-1490.

Morris, M. W., Leung, K., Ames, D., \& Lickel, B. (1999). A view from the inside and the outside: Integrating emic and etic insights about culture and judgement. Academy of Management Review, 24(4), 781-796.

Mosley, L. \& Uno, S. (2007). Racing to the bottom or climbing to the top? Economic globalization and collective labor rights. Comparative Political Studies, 40(8), 923-948.

Negi, R. (2008). Beyond the "Chinese scramble": The political economy of anti-China sentiment in Zambia. African Geographical Review, 27(1), 41-63.

Nonaka, I. (1998). The concept of 'ba': Building a foundation for knowledge creation. California Management Review, 40(3), 40-54.

Ohmae, K. (1996). The End of the Nation State. Cambridge, MA: Free Press.

O'Reilly, C. A. \& Chatman, J. (1986). Organizational commitment and psychological attachment: The effects of compliance, identification, and internalization on prosocial behavior. Journal of Applied Psychology, 71(3), 492-499.

Peterson, S. L. (2004). Toward a theoretical model of employee turnover: A human resource development perspective. Human Resource Development Review, 3(3), 209-227. 
Pisani, N. (2009). International management research: Investigating its recent diffusion in top management journals. Journal of Management, 35(2), 199-218.

Pudelko, M., \& Harzing, A. W. K. (2007). Country-of-origin, localization, or dominance effect? An empirical investigation of HRM practices in foreign subsidiaries. Human Resource Management, 46(4), 535-559.

Schneider, M. R. \& Paunescu, M. (2012). Changing varieties of capitalism and revealed comparative advantages from 1990 to 2005: a test of the Hall and Soskice claims. Socio-Economic Review, 10(4), 731-753.

Schuler, R. S. \& Tarique, I. (2007). International human resource management: A North American perspective, a thematic update and suggestions for future research. International Journal of Human Resource Management, 18(5), 717-744.

Schuler, R. S., Budhwar, P.S., \& Florkowski, G. W. (2002). International human resource management: Review and critique. International Journal of Management Reviews, 4(1), $41-70$.

Scullion, H. \& Brewster, C. (2002). The management of expatriates: Messages from Europe? Journal of World Business, 36(4), 346-365.

Scullion, H. \& Paauwe, J. (2004). International human resource management: Recent developments in theory and empirical research. In Harzing, A.-W. \& Van Ruysseveldt, J. (eds), International Human Resource Management, 2nd edn. London: Sage, 65-88.

Simonin, B. L., \& Özsomer, A. (2009). Knowledge processes and learning outcomes in MNCs: An empirical investigation of the role of HRM practices in foreign subsidiaries. Human Resource Management, 48(4), 505-530.

Szulanski, G. (1996). Exploring internal stickiness: Impediments to the transfer of best practices within the firm. Strategic Management Journal, 17(S2), 27-43. 
Tayeb, M. (1995). The competitive advantage of nations: The role of HRM and its sociocultural context. International Journal of Human Resource Management, 6(3), 588-605.

Tihanyi, L., Johnson, R. A., Hoskisson, R. E., \& Hitt, M. A. (2003). Institutional ownership differences and international diversification: The effects of boards of directors and technological opportunity. Academy of Management Journal, 46(2), 195-211.

Tsui, A. S. (2004). Contributing to global management knowledge: A case for high quality indigenous research. Asia Pacific Journal of Management, 21(4), 491-513.

Tuselmann H. J., McDonald F., \& Thorpe R. (2006). The emerging approach to employee relations in German overseas affiliates: A role model for international operation? Journal of World Business, 41(1), 66-80.

UNCTAD (2017). World Investment Report 2017: Investment and the digital economy. United Nations Conference on Trade and Development, available at http://unctad.org/en/PublicationsLibrary/wir2017_en.pdf

Welch, D. \& Björkman, I., (2015). The place of international human resource management in international business. Management International Review, 55(3), 303-322.

Werner, S. (2002). Recent developments in international management research: A review of 20 top management journals. Journal of Management, 28(3), 277-305.

White, R. \& Poynter, T. (1984). Strategies for Foreign Owned Subsidiaries in Canada. Business Quarterly, 49(2), 59-69.

Whitley, R. (1999). Divergent Capitalisms: The Social Structuring and Change of Business Systems. Oxford: Oxford University Press.

Whitley, R. (2007). Business Systems and Organizational Capabilities. Oxford: Oxford University Press.

Witt, M., De Castro, L., Amaeshi, K., Mahroun, S., Bohle, D., \& Saez, L. (2017). Mapping the Business System of 61 Major Economies: A Taxonomy and Implications for 
Varieties of Capitalism and Business Systems Research. INSEAD Working Paper 2017/07.

Wood, G., Dibben, P. \& Ogden, S. (2014). Comparative Capitalism without Capitalism, and production without workers: The limits and possibilities of contemporary institutional analysis. International Journal of Management Reviews, 16(4), 384-396.

Wood, G. \& Lane, C. (2012). Institutions, change and diversity, Lane, C. and Wood, G. (eds.), Capitalist Diversity and Diversity within Capitalism. London: Routledge.

Zeira, Y. \& Harari, E. (1977). Genuine multinational staffing policy: Expectations and realities. Academy of Management Journal, 20(2), 327-333. 
Table 1. A summary of the key features of other IHRM review/conceptual papers

\begin{tabular}{|c|c|c|c|c|}
\hline Authors & $\begin{array}{r}\text { Focus of the review } \\
\end{array}$ & Period of review & Journal outlets reviewed & Article type \\
\hline $\begin{array}{l}\text { Welch \& Björkman } \\
\text { (2015, MIR) }\end{array}$ & $\begin{array}{l}\text { IHRM field, level of } \\
\text { connectedness/disconnectedness with IB } \\
\text { studies }\end{array}$ & $\begin{array}{l}21 \text { years }(1990-2010) \\
(3 \text { periods })\end{array}$ & $\begin{array}{l}5 \text { IB journals } \\
\text { (IJHRM, JIBS, MIR, JWB, } \\
\text { IBR) }\end{array}$ & Review \\
\hline $\begin{array}{l}\text { Björkman \& Welch } \\
(2015, \text { IJHRM) }\end{array}$ & $\begin{array}{l}\text { IHRM field, four levels Macro, MNC, Unit, } \\
\text { Individual }\end{array}$ & $\begin{array}{l}\text { Conceptual framework } \\
\text { for categorization }\end{array}$ & N/A & Theory \\
\hline $\begin{array}{l}\text { Brewster, } \\
\text { Mayrhofer \& } \\
\text { Smale (2016, } \\
\text { HRMR) }\end{array}$ & $\begin{array}{l}\text { Crossing the streams of HRM in MNEs and } \\
\text { comparative HRM }\end{array}$ & N/A & N/A & Theory \\
\hline $\begin{array}{l}\text { Schuler, Budhwar } \\
\text { \& Florkowski } \\
\text { (2002 IJMR) }\end{array}$ & $\begin{array}{l}\text { IHRM (1) issues, (2) functions, and (3) } \\
\text { policies \& practices }\end{array}$ & N/A & N/A & $\begin{array}{l}\text { Review, not clearly } \\
\text { articulated how the } \\
\text { literature is systematically } \\
\text { reviewed }\end{array}$ \\
\hline $\begin{array}{l}\text { Werner }(2002 \text {, } \\
\text { JOM) }\end{array}$ & $\begin{array}{l}\text { Recent development in international } \\
\text { management, including: } \\
\text { - Transfers of knowledge } \\
\text { - Subsidiary and multinational team } \\
\text { Management; } \\
\text { - Expatriate management }\end{array}$ & $1996-2000$ & $\begin{array}{l}20 \text { top management } \\
\text { journals }\end{array}$ & Systematic review \\
\hline $\begin{array}{l}\text { De Cieri, Wolfram } \\
\text { Cox, Fenwick } \\
(2007, \text { IJMR) }\end{array}$ & IHRM's theoretical development & N/A & N/A & Review \\
\hline $\begin{array}{l}\text { Brewster \& Suutari } \\
(2005 \mathrm{PR})\end{array}$ & Examination key themes in global HRM & N/A & N/A & $\begin{array}{l}\text { Review / Introduction to } \\
\text { SE / outlining research } \\
\text { agenda }\end{array}$ \\
\hline $\begin{array}{l}\text { Schuler \& Tarique } \\
\text { (2007, IJHRM) }\end{array}$ & IHRM North American perspective & $\begin{array}{l}15 \text { years } \\
(1993-2007)\end{array}$ & N/A & $\begin{array}{l}\text { Advancement theoretical } \\
\text { framework + research } \\
\text { agenda ( } 20 \text { avenues for } \\
\text { future research) }\end{array}$ \\
\hline
\end{tabular}


Table 2. List of journals and number of articles found related to studies of HRM in MNCs (2000-2014) (N=342: 293 empirical and 49 review articles)

\begin{tabular}{|c|c|c|}
\hline No. & Journal titles in alphabetical order & No. of articles found \\
\hline 1. & Academy of Management Journal (AMJ) & 7 \\
\hline 2. & Asia Pacific Business Review (APBR) & 20 \\
\hline 3. & Asia Pacific Journal of Human Resources (APJHR) & 13 \\
\hline 4. & Asia Pacific Journal of Management (APJM) & 2 \\
\hline 5. & British Journal of Industrial Relations (BJIR) & 9 \\
\hline 6. & British Journal of Management (BJM) & 3 \\
\hline 7. & Cross Cultural Management (CCM) & 16 \\
\hline 8. & Cambridge Journal of Economics (CJE) & 1 \\
\hline 9. & European Management Journal (EMJ) & 1 \\
\hline 10. & Employee Relations $(E R)$ & 18 \\
\hline 11. & Gender, Work and Organization $(G W O)$ & 2 \\
\hline 12. & Human Relations (HR) & 8 \\
\hline 13. & Human Resource Development International (HRDI) & 1 \\
\hline 14. & Human Resource Management (HRM) & 19 \\
\hline 15. & Human Resource Management Journal (HRMJ) & 11 \\
\hline 16. & Human Resource Management Review (HRMR) & 6 \\
\hline 17. & International Business Review (IBR) & 1 \\
\hline 18. & $\begin{array}{l}\text { International Journal of Cross Cultural Management } \\
\text { (IJCCM) }\end{array}$ & 5 \\
\hline 19. & $\begin{array}{l}\text { International Journal of Human Resource Management } \\
\text { (IJHRM) }\end{array}$ & 102 \\
\hline 20. & Indian Journal of Industrial Relations (IJIR) & 1 \\
\hline 21. & International Journal of Manpower (IJM) & 10 \\
\hline 22. & International Journal of Management Reviews (IJMR) & 1 \\
\hline 23. & Industrial and Labor Relations Review (ILRR) & 7 \\
\hline 24. & Industrial Relations $(I R)$ & 3 \\
\hline 25. & Industrial Relations Journal (IRJ) & 8 \\
\hline 26. & Journal of Asia Business Studies (JABS) & 1 \\
\hline 27. & Journal of Business Ethics (JBE) & 2 \\
\hline 28. & Journal of International Business Studies (JIBS) & 7 \\
\hline 29. & Journal of Industrial Relations (JIR) & 3 \\
\hline 30. & Journal of Management (JOM) & 9 \\
\hline 31. & Journal of Management Studies (JMS) & 5 \\
\hline 32. & Journal of Strategic Information Systems (JSIS) & 1 \\
\hline 33. & Journal of World Business (JWB) & 20 \\
\hline 34. & Organizational Dynamics $(O D)$ & 1 \\
\hline 35. & Organization Studies $(O S)$ & 4 \\
\hline 36. & Personnel Review $(P R)$ & 10 \\
\hline 37. & $\begin{array}{l}\text { Research and Practice in Human Resource Management } \\
\text { (RPHRM) }\end{array}$ & 2 \\
\hline 38. & Singapore Management Review (SMR) & 1 \\
\hline 39. & Thunderbird International Business Review (TIBR) & 1 \\
\hline
\end{tabular}


Table 3. Research methods used by HRM in MNCs empirical studies ( $N=293)$

\begin{tabular}{|c|l|c|c|}
\hline \multicolumn{1}{|l|}{ Research methods } & No. of articles & \% of N \\
\hline \multirow{4}{*}{ Qualitative } & Interviews* & 29 & \\
\cline { 2 - 4 } & Case study/studies (interviews) & 111 & \\
\cline { 2 - 4 } & Ethnographic studies & 6 & \\
\cline { 2 - 4 } & Secondary data & 3 & $51 \%$ \\
\cline { 2 - 4 } & Sub-total & 149 & \\
\hline \multirow{3}{*}{ Quantitative } & Surveys & 89 & $40 \%$ \\
\cline { 2 - 4 } & Secondary data & 27 & \\
\cline { 2 - 4 } & Sub-total & 116 & $10 \%$ \\
\hline \multirow{2}{*}{ Total } & Interviews and surveys & 19 & \\
\cline { 2 - 4 } & Case studies (interviews) and surveys & 9 & \\
\cline { 2 - 4 } & Sub-total & 28 & \\
\hline
\end{tabular}

Note: A total of 342 articles were included in the dataset, 49 of which are review articles which do not contain research methods.

* 'Interviews' refer to studies that only use interviews but not case studies for data collection. Case study is a methodological approach that can include both quantitative (e.g., survey) and qualitative (e.g., interview, focus group) methods. In this review, those studies that use case study as a methodological approach mainly use interviews for data collection, indicating that interview is the main method used in the qualitative and mix-method studies of HRM in MNCs. 
Table 4. Top 15 home and host countries of MNCs studied (numbers in frequency, not number of studies)

\begin{tabular}{|l|c|c|c|c|}
\hline No. & Home countries & Frequency & Host countries & Frequency \\
\hline 1. & USA & 133 & UK & 76 \\
\hline 2. & Japan & 80 & China & 74 \\
\hline 3. & Germany & 72 & Germany & 38 \\
\hline 4. & UK & 59 & USA & 36 \\
\hline 5. & France & 45 & Ireland & 32 \\
\hline 6. & Sweden & 26 & Spain & 28 \\
\hline 7. & China & 25 & France & 25 \\
\hline 8. & Finland & 23 & Australia & 24 \\
\hline 9. & The Netherlands & 23 & Italy & 23 \\
\hline 10. & Switzerland & 20 & India & 19 \\
\hline 11. & Taiwan & 17 & Singapore & 19 \\
\hline 12. & Australia & 15 & Canada & 18 \\
\hline 13. & Korea & 14 & Japan & 17 \\
\hline 14. & Denmark & 13 & Russia & 17 \\
\hline 15. & Spain & 11 & the Netherlands & 17 \\
\hline
\end{tabular}


Table 5. Main thematic topics studied in the HRM in MNCs studies (2000-2014) $(\mathrm{N}=342)$

\begin{tabular}{|c|c|c|c|c|}
\hline Main HRM themes studied & $\begin{array}{l}2000-2004 \\
(\mathrm{~N}=86)\end{array}$ & $\begin{array}{c}2005-2009 \\
(\mathrm{~N}=112)\end{array}$ & $\begin{array}{l}2010-2014 \\
(\mathrm{~N}=144)\end{array}$ & $\begin{array}{l}\text { Entire period } \\
(2000-2014)\end{array}$ \\
\hline \multicolumn{5}{|l|}{ HRM practices } \\
\hline Knowledge management & 3 & 12 & 8 & 23 \\
\hline Staffing & 7 & 8 & 4 & 19 \\
\hline Performance management & 1 & 2 & 4 & 7 \\
\hline Training \& development & 2 & 3 & 2 & 7 \\
\hline Management \& staff localization & 2 & 2 & 2 & 6 \\
\hline Organizational learning & 3 & 1 & 2 & 6 \\
\hline Remuneration \& compensation & 3 & 1 & 2 & 6 \\
\hline Diversity management \& gender equality & 2 & 2 & 1 & 5 \\
\hline Employee turnover \& retention & 1 & 3 & 1 & 5 \\
\hline Global talent management & 0 & 0 & 5 & 5 \\
\hline Talent management in MNCs & 0 & 0 & 4 & 4 \\
\hline Career management & 1 & 0 & 3 & 4 \\
\hline Conflict management & 0 & 1 & 2 & 3 \\
\hline Expatriate adjustment & 0 & 1 & 0 & 1 \\
\hline Inpatriate experiences & 0 & 1 & 0 & 1 \\
\hline Work-life balance & 0 & 1 & 0 & 1 \\
\hline Sub-total & 25 & 38 & 40 & 103 \\
\hline \multicolumn{5}{|l|}{ MNC headquarters - subsidiary relations } \\
\hline Transfer of management \& HR practices & 4 & 10 & 9 & 23 \\
\hline $\begin{array}{l}\text { Global integration vs. local } \\
\text { responsiveness }\end{array}$ & 2 & 4 & 9 & 15 \\
\hline $\begin{array}{l}\text { Subsidiary autonomy \& organizational } \\
\text { control }\end{array}$ & 3 & 3 & 6 & 12 \\
\hline Country-of-origin effect & 4 & 3 & 4 & 11 \\
\hline $\begin{array}{l}\text { Diffusion of HR \& management } \\
\text { practices in MNCs }\end{array}$ & 2 & 3 & 2 & 7 \\
\hline $\begin{array}{l}\text { Adaptation of HRM practices to 'host' } \\
\text { country }\end{array}$ & 1 & 3 & 2 & 6 \\
\hline $\begin{array}{l}\text { Impact of 'home' and 'host' country } \\
\text { effects }\end{array}$ & 3 & 1 & 2 & 6 \\
\hline 'Host' country effects & 0 & 1 & 1 & 2 \\
\hline Sub-total & 19 & 28 & 35 & 82 \\
\hline \multicolumn{5}{|l|}{ Strategic HRM and business studies } \\
\hline Strategic HRM & 6 & 4 & 14 & 24 \\
\hline Organizational structures & 3 & 0 & 4 & 7 \\
\hline Organizational \& subsidiary performance & 3 & 1 & 3 & 7 \\
\hline High performance work systems & 1 & 0 & 2 & 3 \\
\hline Sub-total & 13 & 5 & 23 & 41 \\
\hline \multicolumn{5}{|l|}{ Employment relations } \\
\hline Industrial relations & 8 & 12 & 4 & 24 \\
\hline
\end{tabular}




\begin{tabular}{|c|c|c|c|c|c|}
\hline & $\begin{array}{l}\text { Employee voice, participation \& } \\
\text { representation }\end{array}$ & 2 & 2 & 4 & 8 \\
\hline & Institutional studies & 0 & 4 & 4 & 8 \\
\hline & Sub-total & 10 & 18 & 12 & 40 \\
\hline \multicolumn{6}{|c|}{ Organizational behavior } \\
\hline & Organizational commitment & 0 & 1 & 4 & 5 \\
\hline & $\begin{array}{l}\text { Management \& employee perceptions / } \\
\text { experiences / reactions }\end{array}$ & 0 & 0 & 5 & 5 \\
\hline & Organizational identification & 1 & 0 & 3 & 4 \\
\hline & Leadership & 0 & 1 & 2 & 3 \\
\hline & Job satisfaction & 0 & 0 & 2 & 2 \\
\hline & Employee motivation factors & 0 & 1 & 0 & 1 \\
\hline & Perceived organizational support & 0 & 0 & 1 & 1 \\
\hline & Person-job fit & 0 & 0 & 1 & 1 \\
\hline & Social identification & 0 & 1 & 0 & 1 \\
\hline & Teamworking & 1 & 0 & 0 & 1 \\
\hline & $\begin{array}{l}\text { Workplace boundaries \& boundary } \\
\text { permeability }\end{array}$ & 0 & 1 & 0 & 1 \\
\hline & Work values & 0 & 0 & 1 & 1 \\
\hline & Sub-total & 2 & 5 & 19 & 26 \\
\hline \multicolumn{6}{|c|}{ Cultural studies } \\
\hline & Cross-cultural studies / adaptation & 1 & 4 & 3 & 8 \\
\hline & Cultural focus & 4 & 3 & 1 & 8 \\
\hline & Cultural distance / difference & 2 & 3 & 0 & 5 \\
\hline & Sub-total & 7 & 10 & 4 & 21 \\
\hline \multicolumn{6}{|c|}{ Comparative HRM } \\
\hline & $\begin{array}{l}\text { Comparisons MNCs with indigenous } \\
\text { firms }\end{array}$ & 4 & 3 & 4 & 11 \\
\hline & Sub-total & 4 & 3 & 4 & 11 \\
\hline \multicolumn{6}{|c|}{$\begin{array}{l}\text { Language \& communication in international } \\
\text { business }\end{array}$} \\
\hline & Sub-total & 0 & 1 & 1 & 2 \\
\hline Others & $\begin{array}{l}\text { HR issues in relation to particular } \\
\text { countries or contexts }\end{array}$ & 4 & 3 & 3 & 10 \\
\hline & $\begin{array}{l}\text { IHRM scholarship reviews and theory } \\
\text { development }\end{array}$ & 2 & 1 & 3 & 6 \\
\hline & Sub-total & 6 & 4 & 6 & 16 \\
\hline
\end{tabular}


Table 6. A summary of theories most used*

\begin{tabular}{|c|c|c|}
\hline No. & Category of theories & Example of theories used \\
\hline 1. & Institutional theories (122) & $\begin{array}{l}\text { Institutional theories/framework; neo/new institutional } \\
\text { theory/framework); national business systems } \\
\text { (frameworks)/variety of capitalism; comparative } \\
\text { institutional theory; isomorphism; convergence vs. } \\
\text { divergence; standardization vs. local responsiveness; } \\
\text { societal effect; duality perspective; dominance effects; } \\
\text { home-country and host-country effect }\end{array}$ \\
\hline 2. & $\begin{array}{l}\text { Resource-based view and } \\
\text { resource-dependence } \\
\text { theories (37) }\end{array}$ & $\begin{array}{l}\text { Resource-based view; resource-dependence } \\
\text { perspective; competency-based view; structural } \\
\text { perspective on capability evaluation }\end{array}$ \\
\hline 3. & $\begin{array}{l}\text { Organizational } \\
\text { behavior/psychology } \\
\text { theory }(35)\end{array}$ & $\begin{array}{l}\text { AMO-framework; organizational identity; } \\
\text { organizational identification; identity theory; } \\
\text { organizational capabilities theory; organizational } \\
\text { commitment; theory of job demands; (combination of } \\
\text { aspects of) role theory and cognitive choice heuristics } \\
\text { (organizational behavior); person-organization fit } \\
\text { theory; person-environment fit theory; motivation } \\
\text { theory; expectancy theory; equity theory } \\
\text { (organizational justice) perspective; fairness heuristic } \\
\text { theory; role episode theory; new leadership identity } \\
\text { construction theory; leadership theory; bounded } \\
\text { rationality theories; dual commitment theory; } \\
\text { supportiveness and dependability theory }\end{array}$ \\
\hline 4. & $\begin{array}{l}\text { Strategic HRM and } \\
\text { industrial relations } \\
\text { perspectives (32) (also see } \\
\text { below for contingency } \\
\text { theory) }\end{array}$ & $\begin{array}{l}\text { Strategic IHRM; strategic HRM (best-practice, } \\
\text { contingency and configurational perspectives); } \\
\text { integrated IHRM approach; employee participation; } \\
\text { high-involvement/performance work systems; } \\
\text { Tuselman et al.'s (2006) model for employee voice; } \\
\text { Lavelle et al.'s (2010) employee voice model; } \\
\text { Hirschman's (1970) exit-voice theory; Bryson's (2004) } \\
\text { voice arrangements; voice theory (exit-voice); Freeman } \\
\text { et al.'s (2007) representative based forms of voice }\end{array}$ \\
\hline 5. & Culture perspective (30) & $\begin{array}{l}\text { Hofstede's (1980) theory on cultural value dimensions; } \\
\text { culturalist perspective; cross-cultural management } \\
\text { theory; universalism-cultural relativism; acculturation } \\
\text { theory; dynamic vs static cultural perspective; } \\
\text { management by values theory; crossvergence theory; } \\
\text { organizational culture perspective }\end{array}$ \\
\hline 6. & $\begin{array}{l}\text { Grounded } \\
\text { theory/inductive theory } \\
\text { building (22) }\end{array}$ & Grounded/emergent theory; inductive theory building \\
\hline 7. & $\begin{array}{l}\text { Conceptual/theoretical } \\
\text { model or analytical } \\
\text { framework (note: in this } \\
\text { category, authors adopt } \\
\text { particular analytical }\end{array}$ & $\begin{array}{l}\text { Cappelli's (2008) 'talent on demand' framework; } \\
\text { Framework of stickiness (Szulanski, 1996); Deutsch's } \\
\text { (1973) theory of co-operation and competition; 'scope' } \\
\text { framework (White \& Poynter 1984); Nonaka's (1998) } \\
\text { SECI (Socialization, Externalization, Combination, }\end{array}$ \\
\hline
\end{tabular}




\begin{tabular}{|c|c|c|}
\hline & $\begin{array}{l}\text { framework or model to } \\
\text { use and/or extend in their } \\
\text { study) (21) }\end{array}$ & $\begin{array}{l}\text { Internalization) model; Grant's (1996) knowledge } \\
\text { integration approach; Dunning's (1988) OLI } \\
\text { (ownership, Localization, Internalization) framework; } \\
\text { Peterson's (2004) model of human resource } \\
\text { development (HRD); Foucault's (1991) social theory }\end{array}$ \\
\hline 8. & Social capital theory (20) & $\begin{array}{l}\text { Actor Network Theory; social resources theory; social } \\
\text { network theory; trust; social capital theory; social } \\
\text { exchange theory; relational perspective }\end{array}$ \\
\hline 9. & $\begin{array}{l}\text { Organizational studies } \\
\text { (18) }\end{array}$ & $\begin{array}{l}\text { Organizational strategy (Goffman's (1956) theories of } \\
\text { strategic self-presentation); organizational strategy; } \\
\text { change management theory; control theory; dynamic } \\
\text { capabilities perspective; job embeddedness theory; } \\
\text { strategic integration model; inter-organization theory; } \\
\text { uncertainty management model; economic rationality; } \\
\text { subsidiary capabilities; organizational discourse }\end{array}$ \\
\hline 10. & Political perspective (17) & $\begin{array}{l}\text { Political perspective; pluralist industrial relations } \\
\text { perspective; social political perspective; micro-political } \\
\text { perspective; micro-political theory; political-economy } \\
\text { theory; micro-political economy; power of actors IR } \\
\text { theory; power-based framework of analysis of MNC } \\
\text { HQ-subsidiary relations }\end{array}$ \\
\hline 11. & $\begin{array}{l}\text { Human capital theories } \\
\text { (15) }\end{array}$ & $\begin{array}{l}\text { Human capital theories; knowledge management; } \\
\text { competitive advantage of talent management } \\
\text { perspective; relational perspective of human capital; } \\
\text { efficiency generally associated with experience } \\
\text { perspective; disseminative capacity (ability and } \\
\text { willingness) }\end{array}$ \\
\hline 12. & $\begin{array}{l}\text { Power resource/strategic } \\
\text { choice (12) }\end{array}$ & $\begin{array}{l}\text { Bargaining power perspective; power/interests } \\
\text { perspective; power resource/strategic choice; Lukesian } \\
\text { (1975) perspective of the dimensions of power; } \\
\text { strategic choice; strategic change }\end{array}$ \\
\hline 13. & Agency theory (12) & Human agency; agency theory \\
\hline 14. & Contingency theory (11) & $\begin{array}{l}\text { Contingency perspective (decisional convergence); } \\
\text { contingency framework; contingency or fit theory; } \\
\text { contingency theory }\end{array}$ \\
\hline 15. & Economic theories (10) & $\begin{array}{l}\text { Transaction cost theory; perceived cost theory; cost- } \\
\text { benefit analysis; deficit theories; classical economic } \\
\text { theory; neo- classical economics }\end{array}$ \\
\hline 16. & $\begin{array}{l}\text { International business (IB) } \\
\text { (8) }\end{array}$ & $\begin{array}{l}\text { Ownership-Location-Internalization paradigm (e.g. } \\
\text { Dunning, 1975; Hymer, 1976); global value chain } \\
\text { effects; spillover effect; economic proposition FDI } \\
\text { literature ; internationalization theory; global reach } \\
\text { theory; motives of internationalization and entry } \\
\text { strategy }\end{array}$ \\
\hline 17. & Social identity theories $(7)$ & Social identification theory; social identity theory \\
\hline 18. & Learning theories (6) & $\begin{array}{l}\text { Organizational learning theory; social learning theory; } \\
\text { learning theory }\end{array}$ \\
\hline 19. & Control theories (4) & $\begin{array}{l}\text { Control theories (output, behavior and cultural); } \\
\text { organizational control; control theories; Harzing's } \\
\text { (1999) typology of control }\end{array}$ \\
\hline
\end{tabular}




\begin{tabular}{|c|l|l|}
\hline 20. & Social cognitive theory (3) & $\begin{array}{l}\text { Cognition based search and choice; social justice } \\
\text { perspectives; social cognitive theory }\end{array}$ \\
\hline 21. & $\begin{array}{l}\text { Gender/feminist theories } \\
(2)\end{array}$ & $\begin{array}{l}\text { Feminist perspective; gender theory (vertical gender } \\
\text { inequality lens) }\end{array}$ \\
\hline
\end{tabular}

* Number in the bracket refers to the number of papers that have used the particular theory.

Some papers use more than one theory. This table includes the majority but NOT all the theories that have been used in the 342 articles. 